\title{
To the Question About Intracellular Polyhydroxybutyrate Degradation
}

\author{
Natalia O. Zhila $a^{\mathrm{a}, \mathrm{b}}$, \\ Galina S. Kalacheva ${ }^{* a, b}$ and Tatiana G. Volova ${ }^{a, b}$ \\ ${ }^{a}$ Institute of Biophysics SB RAS \\ 50/50 Akademgorodok, Krasnoyarsk, 660036, Russia \\ ${ }^{b}$ Siberian Federal University \\ 79 Svobodny, Krasnoyarsk, 660041, Russia
}

Received 12.01.2015, received in revised form 19.02.2015, accepted 18.04.2015

The investigation of dynamics of $1,2{ }^{14} C$-acetate flows was carried out in three different regimes of bacteria Cupriavidus eutrophus B-10646 biosynthesis on fructose and acetate: a) in the phase of accumulation of polyhydroxybutyrate; $b)$ in the phase of intracellular PHB degradation and the synthesis of nitrogen compounds; c) in the phase of resynthesis of PHB. It has been shown that in regime of $P H B$ accumulation $80 \%$ of labeled carbon was used for synthesis of PHB. At the condition of PHB degradation both synthesis and degradation take place simultaneously. This confirms the cyclic nature of PHB methabolism.

Keywords: cupriavidus eutrophus B-10646, 1,2 ${ }^{14}$ C-acetate, polyhydroxybutyrate, biosynthesis, intracellular degradation.

DOI: $10.17516 / 1997-1389-2015-8-2-220-235$.

(C) Siberian Federal University. All rights reserved

* Corresponding author E-mail address: kalach@ibp.ru 


\title{
К вопросу о внутриклеточной деградации полигидроксибутирата
}

\author{
Н.О. Жила ${ }^{\mathrm{a}, \tilde{0}}$, Г.С. Калачева ${ }^{\mathrm{a}, \tilde{0}}$, Т.Г. Волова ${ }^{\mathrm{a}, \boldsymbol{0}}$ \\ ${ }^{a}$ Институт биофизики СО РАН \\ Россия, 660036, Красноярск, Академгородок, 50/50 \\ ${ }^{6}$ Сибирский федеральный университет \\ Россия, 660041, Красноярск, пр. Свободный, 79
}

Исследованы в динамике потоки меченого углеродного субстрата $\left(1,2^{14}\right.$ C-ацетата) в меняюшихся режимах биосинтеза бактерий Cupriavidus eutrophus B-10646 при росте на фруктозе и ацетате: а) в ходе накопления запасного соединения - полигидроксибутирата (ПГБ), б) эндогенной деградации ПГБ и синтеза азотсодержащих компонентов, в) ресинтеза ПГБ. Показано, что при выращивании бактерий C. еиtrophus B-10646 в режиме аккумуляции ПГБ на фруктозе и ацетате в период накопления полимера в среднем около $80 \%$ радиоуглерода направляется на его синтез. Установлено, что вусловиях, благоприятных для внутриклеточной деградации ПГБ, также происходит синтез полимера, что подтверждает предположение об одновременном синтезе и деградаџии полимера в клетках бактерий.

Ключевые слова: Cupriavidus eutrophus B-10646, 1,2 ${ }^{14}$ C-ачетат, полигидроксибутират, биосинтез, внутриклеточная деградащия.

\section{Введение}

Полигидроксиалканоаты (ПГА), активно изучаемые в настоящее время в связи с их биодеградируемостью, относятся к резервным макромолекулам и образуются прокариотами при несбалансированном росте как эндогенное депо энергии и углерода. ПГА синтезируются в ходе сложного многоступенчатого биосинтетического процесса, каждую стадию которого катализируют специфические ферменты. Синтез ПГА в общих чертах сходен у различных микроорганизмов, но наиболее изучены пути синтеза полигидроксибутирата (ПГБ) у типового штамма Ralstonia eutropha Н16 в различных условиях несбалансированного роста (Lee, 1996; Fukui et al., 2013; Shimizu et al., 2013; Przybylsky et al., 2015).

Биосинтез ПГБ начинается с конденсации двух молекул ацетил-КоА до
ацетоацетил-КоА, восстанавливающийся

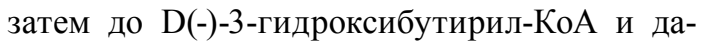
лее включающийся в полимерную цепь. Все эти этапы катализируются в основном тремя ферментами: $\beta$-кетотиолазой, НАДФН зависимой ацетоацетил-КоА-редуктазой и ПГБ-полимеразой (синтазой) (Haywood et al., 1989). Факторы, регулирующие их активности на генетическом и молекулярном уровнях, интенсивно изучаются, и считается, что $\beta$-кетотиолаза запускает синтез полимера, peдуктаза регулирует скорость синтеза ПГБ, а синтаза отвечает за качественные характеристики полимера (молекулярный вес, мономерный состав) и конечный выход ПГА (Lawrence et al., 2005; Fukui et al., 2013; Sznajder et al., 2015).

Однако процесс формирования полимера достаточно сложен и определяется не только 
ферментами синтетической ветви цикла ПГА, но и другими аспектами полимерного метаболизма. Не менее важной представляется роль ферментов деполимеризующей ветви цикла ПГА, которые могут регулировать как молекулярный вес ПГА, так и его конечный выход. Однако процесс внутриклеточной деградации ПГБ менее изучен. Деградация ПГА происходит через гидролиз и тиолиз. Последняя реакция является результатом действия ПГАсинтазы, но в обратном направлении. Впервые возможность участия ПГА-синтазы не только в синтезе, но и в деградации полимера показана в работе Uchino and Saito (2006). Но физиологическая значимость этой реакции пока не ясна.

Гидролиз и тиолиз полимера происходят под действием ПГА-деполимераз. Впервые деполимеразный ген в Ralstonia eutropha H16 был клонирован в 2001 г. (Saeguse et al., 2001), а в 2003 г. были охарактеризованы еще 3 деполимеразы (York et al., 2003). В настоящее время известно 7 типов деполимераз, две из них (phaZ1 and phaZ6) активно экспрессируются в фазу аккумуляции ПГА (Lawrence et al., 2005; Shimizu et al., 2013; Sznajder et al., 2015). В процессе гидролиза полимера образуются мономеры и олигомеры. Последние разрушаются до мономеров под действием гидролаз. В Ralstonia eutropha обнаружены две гидролазы, участвующие в разрушении олигомеров (Kobayashi et al., 2005).

Существует достаточно много фактов, свидетельствующих о том, что синтез и деградация полимера в клетке происходят одновременно. Впервые предположение о циклической природе метаболизма ПГА в Alkaligenus eutrophus было высказано Дои с соавторами (Doi et al., 1990), которые показали, что перенос культуры, выращенной на пентановой кислоте, а следовательно, синтезирующей ПГА с высоким содержанием 3-гироксивале- рата (3-ГВ) - до 49 мол \% в ПГА, на среду с бутиратом происходит заметное снижение фракции 3-ГВ в полимере (до 19 \%) без изменения его содержания в клетке. Аналогичные результаты для бактерий $R$. eutropha NCIMB 11599 были получены Шенгом с соавторами (Shang et al., 2005). В работе (Taidi et al., 1995) в опытах с A. eutrophus NSMB40529 и меченой глюкозой выявлено, что накопление метки в полимере продолжалось даже после прекращения его аккумуляции. Кроме того, показано, что в процессе синтеза полимера происходила постепенная замена полимера с высокой молекулярной массой полимером с более низкой молекулярной массой. Однако в работе Хэйвуда с соавторами (Haywood et al., 1989) доказательств существования одновременного синтеза и деградации ПГБ у бактерий A. eutrophus, культивируемых в хемостате, находящихся в устойчивом состояниилимитирования азотом, не получено. Нами установлено, что в период накопления полимера в клетках активность деполимеризующих полимер ферментов (ПГБ-деполимеразы и гидроксибутиратдегидрогеназы) была низкой и проявлялась только при стимулировании эндогенной деградации ПГБ (культивирование бактерий при лимите или отсутствии экзогенного источника углерода и энергии) (Volova et al., 2004). Противоречивость данных разных авторов была несколько разрешена недавней работой Учино с соавторами (Uchino et al., 2007), которые показали, что в нативных гранулах полимера, во-первых, локализуются все ферменты синтеза полимера ( $\beta$-кетотиолаза, редуктаза и синтаза) и деполимераза PhaZal, обладающая тиолазной активностью, продуктом реакции которой является 3-НВ-СоА. Следовательно, деградация полимера является энергонезависимым процессом и может происходить одновременно с его синтезом. Во-вторых, баланс между синтезом и деградацией полимера 
регулируется внутриклеточными концентрациями ключевых метаболитов - КоА, ацетилКоА, ЗНВ-КоА, НАД ном уровне. В более ранней работе (Handrick et al., 2000) авторы предсказали возможность регулирования активностей синтазы и деполимеразы в зависимости от концентраций специфических субстратов - 3НВ-КоА - для синтазы и ПГБ - для деполимеразы. Авторы предположили, что эти ферменты могут отвечать за сбалансированные изменения потока углерода, исходящие из углеводного субстрата через ацетил-КоА. Если клетка при росте не испытывает дефицита в углероде, уровень ацетил-КоА выше его потребления, активность синтазы будет высока, а активность деполимеразной ветви будет снижена, что стимулирует синтез ПГБ. Снижение поступления углеродного субстрата приведет к снижению концентрации ацетил-КоА, и, следовательно, будет повышаться активность деполимераз, поэтому необходимо изучать механизм регуляции активностей этих двух ветвей одновременно в условиях синтеза и деградации ПГБ.

Понимание механизмов взаимодействия двух ветвей метаболизма ПГА важно для направленного изменения свойств и структур синтезируемых клетками полимеров. Одним из подходов к изучению этих взаимодействий является выяснение внутриклеточного распределения меченого субстрата в процессе роста бактерий в условиях синтеза и деградации полимера.

Публикации, посвященные анализу метаболических путей цикла ПГБ с применением меченого субстрата, немногочисленны. В работе (Haywood et al., 1989) было исследовано включение ${ }^{14} \mathrm{C}$ в Alcaligenes eutrophus NCIB 11599. Авторы показали, что динамика включения радиоуглерода в полимер аналогична динамике биомассы. Учино с соавтора- ми (Uchino et al., 2007) использовали меченый ацетил-КоА для доказательств способности нативных ПГБ гранул катализировать все реакции, приводящие к синтезу полимера. С

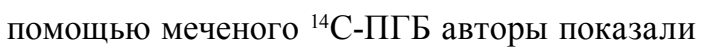
тиолазную активность ПГБ-синтазы (Uchino and Saito, 2006). В работе Shimizu et al. (2013) был использован $\mathrm{NaH}^{13} \mathrm{CO}_{3}$ для выяснения роли цикла Кальвина в синтезе ПГБ. При исследовании закономерностей образования сополимеров 3-HB/3-HV метилотрофными бактериями в присутствии меченых по углероду ко-субстратов (пропионата и валерата) показано, что количество радиоуглерода в сополимере от общего количества радиоактивности, найденной в биомассе, может составлять от 16 до 69 \% (Korotkova et al., 1999). Других данных по изучению метаболизма ПГА микроорганизмов с мечеными субстратами в доступной нам литературе не найдено.

Целью настоящей работы было исследование распределения радиоуглерода среди макромолекул у бактерий Cupriavidus eutrophus B-10646 при аккумуляции и эндогенной деградации полигидроксибутирата.

\section{Материалы и методы}

Исследован штамм Cupriavidus eutrophus B-10646 (ранее Alcaligenus, Ralstonia, Wautersia, Cupriavidus) (Vaneechoutte et al., 2004), депонированный во Всероссийской коллекции промышленных микроорганизмов (ВКПМ) (Волова, Шишацкая, 2012). Штамм имеет широкий органотрофный потенциал и может использовать большой спектр органических субстратов. C. eutrophus B-10646 толерантен к ряду органических субстратов, таких как валериат, гексаноат, бутиролактон в концентрациях от 3 до 5 г/л в культуральной среде, которые используются для синтеза коротко- и среднецепочечных ПГА (Волова, Шишацкая, 2012; Volova et al., 2014). 


\section{Условия культивирования}

Культивирование бактерий C. eutrophus B-10646 проводили в колбах объемом 1 л на минеральной среде Шлегеля следующего состава (Г/л): $\mathrm{Na}_{2} \mathrm{HPO}_{4} \cdot \mathrm{H}_{2} \mathrm{O}-9.1 ; \mathrm{KH}_{2} \mathrm{PO}_{4}-1.5$; $\mathrm{MgSO}_{4} \cdot \mathrm{H}_{2} \mathrm{O}-0.2 ; \mathrm{Fe}_{3} \mathrm{C}_{6} \mathrm{H}_{5} \mathrm{O}_{7} \cdot 7 \mathrm{H}_{2} \mathrm{O}-0.25$; $\mathrm{NH}_{4} \mathrm{Cl}-1.0$ (Schlegel et al., 1961). Микроэлементы вводили по прописи Хоагланда из расчета 3 мл стандартного раствора на 1 л среды. Стандартный раствор микроэлементов содержит (г/л): $\mathrm{H}_{3} \mathrm{BO}_{3}-1.5 ; \mathrm{CoCl}_{2} \cdot 6 \mathrm{H}_{2} \mathrm{O}-0.03$; $\mathrm{CuSO}_{4} \cdot 5 \mathrm{H}_{2} \mathrm{O}-0.008 ; \mathrm{MnCl}_{2} \cdot 4 \mathrm{H}_{2} \mathrm{O}-0.008$; $\mathrm{ZnSO}_{4} \cdot 7 \mathrm{H}_{2} \mathrm{O}-0.176 ; \mathrm{NaMoO}_{4} \cdot 2 \mathrm{H}_{2} \mathrm{O}-0.05$; $\mathrm{NiCl}_{2}-0.008$.

Бактерии выращивали в режиме синтеза и деградации полимера (Волова и др., 1992; Kalacheva and Volova, 2007). На первом этапе бактерии культивировали с лимитированным содержанием азота в среде (50\% от потребностей культуры в элементе) в режиме максимальной аккумуляции полимера. На втором этапе добавляли в культуру хлорид аммония (1 г/л) для инициирования процесса деградации полимера; третий этап аналогичен первому (после исчерпания $\mathrm{NH}_{4} \mathrm{Cl}$ снова были созданы условия для накопления полимера). Проведено три эксперимента. В первом эксперименте в качестве углеродного субстрата использовали фруктозу, поддерживая ее концентрацию в среде на уровне 10-13 г/л и снижая до 5 г/л в фазу деградации полимеpa. В остальных экспериментах в качестве углеродного субстрата использовали ацетат натрия (5 г/л). $\mathrm{pH}$ среды поддерживали на уровне 7.0 - 7.2 добавлением в среду титрующего агента (100 мл $\mathrm{CH}_{3} \mathrm{COOH} / л$ дистиллиро-

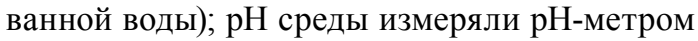
(pH-Meter 766, Calimatic, Germany).

В первом и втором экспериментах в культуру бактерий вносили меченый углеродный субстрат $\left(1,2-{ }^{14} \mathrm{C}\right.$-ацетат) на стадии синтеза полимера (24-й час культивирова- ния), а в третьем эксперименте - на стадии внутриклеточной деградации (115-й час культивирования) - 0.02 и 0.04 мкКи/мл соответственно. Пробы культуры для анализов отбирали через $0.5,1$ и 2 ч после добавления метки; далее отбор проб производили через 10-28 ч в течение экспериментов. При наступлении третьей фазы эксперимента культивирование продолжали 38-75 ч. Анализировали динамику радиоактивности культуральной среды, биомассы, липидов, полимера и «активной» биомассы (биомасса без липидов и полимера).

\section{Аналитические методы}

Биомассу культуры определяли по весу сухого вещества и измерением оптической плотности. Содержание аммонийного азота в культуральной среде определяли с реактивом Несслера. Концентрацию глюкозы - в среде резорциновым методом.

Содержание полимера в биомассе измеряли хроматографией метиловых эфиров жирных кислот после метанолиза проб сухой биомассы на хромато-масс-спектрометре (7890/5975C, Agilent Technologies, U.S.) (Brandl et al., 1988), используя в качестве внутреннего стандарта бензойную кислоту, и весовым методом после экстракции хлороформом и осаждения гексаном.

Молекулярный вес ПГБ исследовали гель-проникающей хроматографией (модель 1260 Infinity, Agilent Technologies, США) с рефрактометрическим детектором, используя колонку Agilent PLgel Mixed-C. В качестве элюента был применен хлороформ. Калибровка проводилась по полистериновым стандартам (Fluka, Швейцария, Германия). Были определены средневесовая молекулярная масса - Mw, среднечисловая молекулярная масса - Mn и полидисперсность $(\bigoplus=\mathrm{Mw} / \mathrm{Mn})$. 
Липиды и полимер из биомассы выделяли смесью хлороформа и метанола (2:1, по объему). Полимер отделяли от липидов осаждением двойным объемом гексана (Калачева, Волова, 2007). Полученный экстракт липидов переносили в предварительно взвешенную колбу, растворитель отгоняли на роторном испарителе, доводили в эксикаторе до постоянного веса и взвешивали.

Определенный объем культуральной среды, биомассу, полимер, липиды и «активную» биомассу, предварительно взвешенные, помещали в пластиковые виалы (“Perkin Elmer/ Packard", США) с 10 мл сцинтилляционного раствора (10 г 2.5 - дифенилоксазола, 0.25 г 1,3-ди-2,5-фенилоксазолил бензола, 100 г нафталина в 1 л диоксана). Радиоактивность проб измеряли на сцинтилляционном счетчике Tri-Carb 2100 TR («Packard Instrument Company», США).

\section{Результаты и обсуждение}

Рост культуры на фруктозе

Длительность эксперимента на фруктозе составила 256 ч. Периодичность отбора проб была следующей: первый отбор проб произвели при плотности биомассы около 1 г/л, затем через 24 ч, когда плотность биомассы составила около 2.5 г/л, был добавлен меченый ацетат и в течение часа были отобраны две пробы. Затем периодичность отбора проб составила 24-28 ч.

Содержание основных субстратов в среде показано на рис. 1а. В течение роста концентрация фруктозы поддерживалась на уровне 10-13 г/л, но в период эндогенной деградации полимера содержание этого субстрата было снижено приблизительно в 2 раза (до 5-6 г/л), а затем возвращено к исходным значениям. Содержание азота в среде к началу активного синтеза полимера снижалось с 1 г/л до аналитического нуля. На втором этапе культивиро- вания после однократного внесения хлористого аммония концентрация азота поднималась до исходного уровня, а затем в течение 72 ч снова падала до нуля (рис. 1a).

Кривые роста и динамика накопления ПГБ у бактерии C. eutrophus B-10646, выращиваемой на фруктозе в режиме, позволившем организовать смену направленности синтеза основных (азотсодержащие компоненты) и запасных (полигидроксибутират) клеточных макромолекул, представлены на рис. 1б. В течение первого периода (41-136 ч) были созданы условия для аккумуляции полимера в клетках (дефицит азота в среде). Во втором периоде роста (136-208 ч) на полной питательной среде происходила эндогенная деградация полимера; на третьем этапе после исчерпания азота из культуральной среды (208-256 ч) происходил ресинтез полимера, a затем его деградация, связанная с прекращением роста культуры и ее гибелью.

Концентрация биомассы несущественно возрастала в течение 100 ч культивирования и не превышала 4 г/л. После внесения в среду азота на 136-й час эксперимента биомасса увеличилась более чем в 2 раза (с 4 до 9 г/л). По мере исчерпания в среде азота рост клеток прекратился и концентрация биомассы несколько снизилась - до 7.3 г/л и оставалась на этом уровне до конца эксперимента (рис. 1б). В начале роста азотсодержащие вещества клетки составляли более $60 \%$ от сухого веса биомассы, а содержание полимера не превышало $22 \%$ (рис. 1б). По мере исчерпания в среде азота происходили существенные изменения в составе биомассы. Уровень полимера в биомассе возрастал до 80-88 \% (или с 0.2 до 3.9 г/л), при этом содержание общего азота снижалось до 1.2-2 \% или 8-12 \% белка. На втором этапе опыта, после добавления в среду хлорида аммония, были созданы условия для перераспределения углерода, запасенного в 


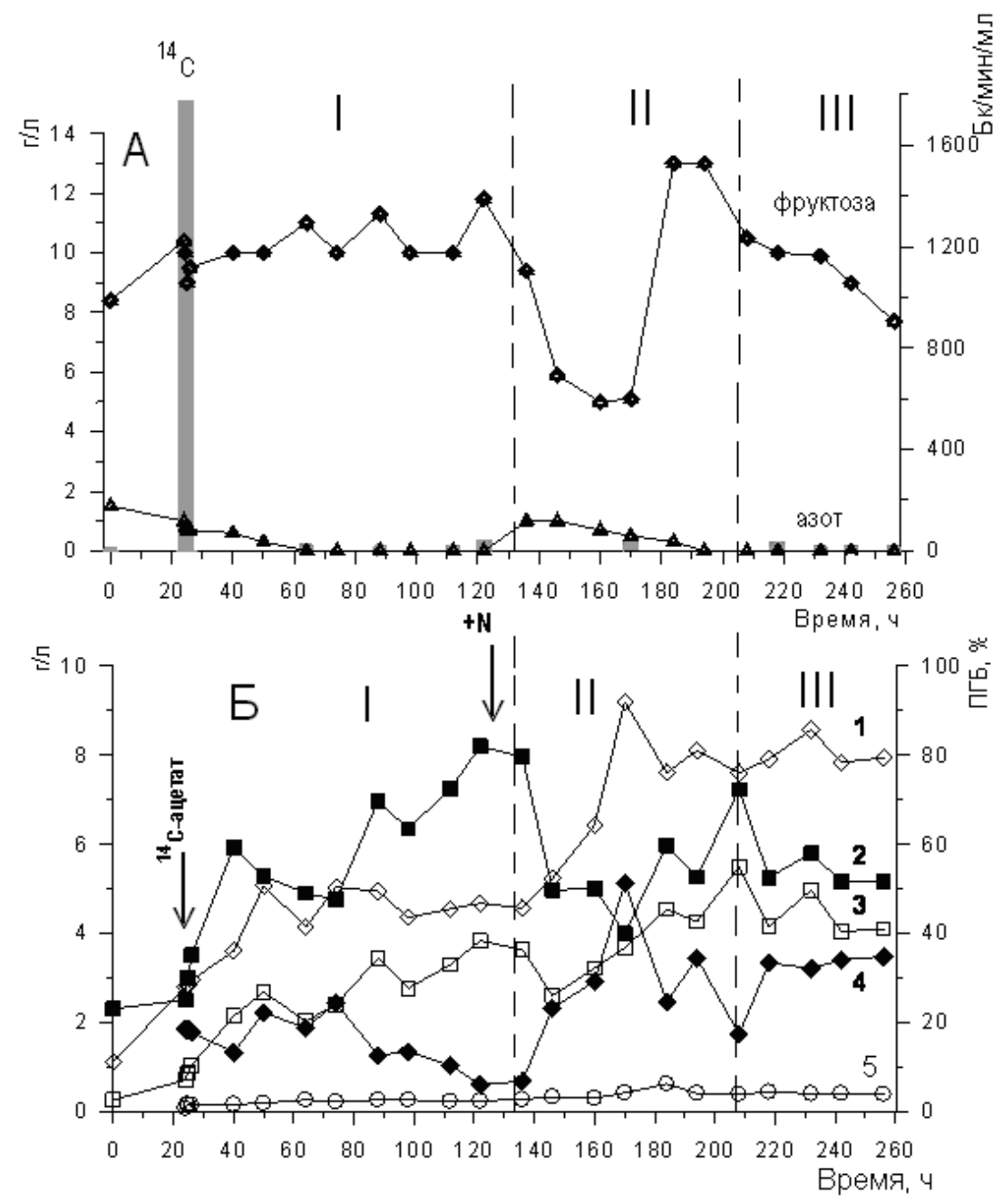

Рис. 1. Содержание в культуральной среде фруктозы (г/л), азота (г/л) и 1,2- ${ }^{14} \mathrm{C}$-ацетата (МБк/мин/мл) (а) и показатели культуры бактерий (б) (1 - биомасса, г/л; 2 - ПГБ, \%; 3 - «активная» биомасса, г/л; 4 - ПГА, г/л; 5 - липиды, г/л) при выращивании Cupriavidus eutrophus B-10646 при смене режимов биосинтеза (I), внутриклеточной деградации (II) и ресинтеза ПГБ (III). Стрелками показано добавление в культуру 1,2${ }^{14} \mathrm{C}$-ацетата и хлорида аммония

полимере, в другие синтетические пути. При этом содержание полимера в биомассе снизилось до 40 \% и увеличивалось содержание азотистых компонентов клетки (до $4.5 \%$ общего азота или $25 \%$ белка). После исчерпания в среде азота снова наблюдался ресинтез полимера и снижение в клетках общего азота. Следует отметить, что изменяющиеся ростовые условия существенно влияли на соотношение полимера и общего азота в клетках, при этом содержание липидов оставалось практически постоянным на протяжении всего опыта и составляло 5-7 \% от сухого вещества.

На фоне этих изменений было измерено распределение активности в культуральной среде, биомассе и отдельных фракциях клетки. В течение первых 2 часов культивирования после внесения $1,2-{ }^{14} \mathrm{C}$-ацетата количество меченого углерода в культуральной среде резко упало с 1776 до 10-12 Бк/мин/мл 


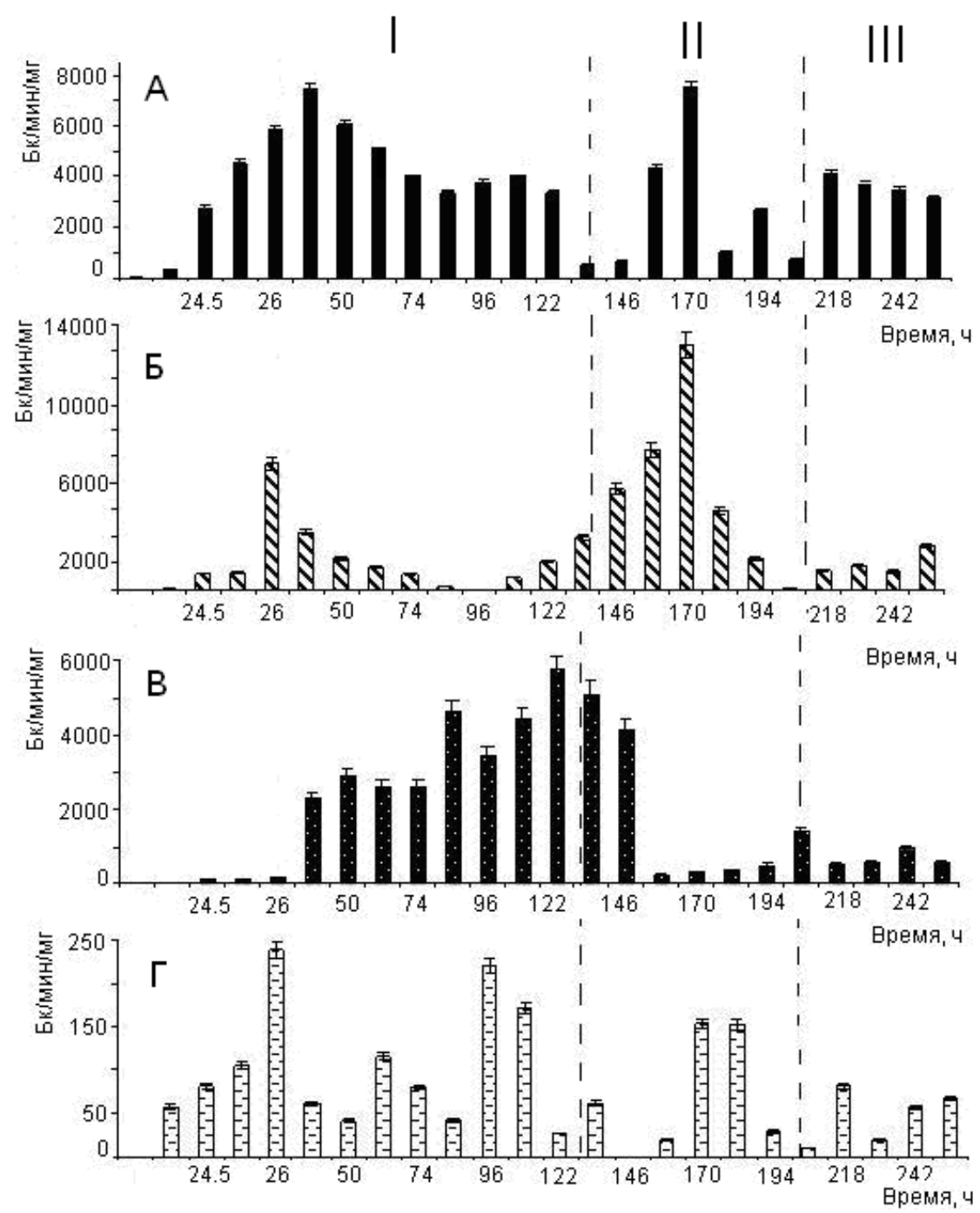

Рис. 2. Динамика удельной активности радиоуглерода в биомассе Cupriavidus eutrophus B-10646 (a), «активной» биомассе (б), ПГБ (в) и липидах (г) при смене режимов биосинтеза (I), деградации (II), ресинтеза ПГБ (III)

(рис. 1). Метка практически сразу же начала включаться в биомассу (рис. 2а) и в первую очередь во фракцию липидов (рис. 2г). Затем отмечалось появление метки в «активной» биомассе (рис. 2б) и только после 40 часов роста культуры меченый углерод активно начал включаться в полимер и уровень включения ${ }^{14} \mathrm{C}$ возрастал вплоть до перехода культуры на 2-й этап роста на полной питательной среде (рис. 2в), сопровождающий деградацией полимера и активизацией синтеза азотсодержа- щих соединений. Включение радиоуглерода в полимер уменьшилось (рис. 2в) на фоне существенного увеличения метки в «активной» биомассе (рис. 2б).

На третьем этапе (начиная с 208 ч) после исчерпания азота в культуре снова были созданы условия для накопления в клетках полимера. Культивирование бактерий на среде без азота сопровождалось сначала увеличением пула полимера от 40 до $72 \%$, однако в дальнейшем синтез полимера прекратился, 


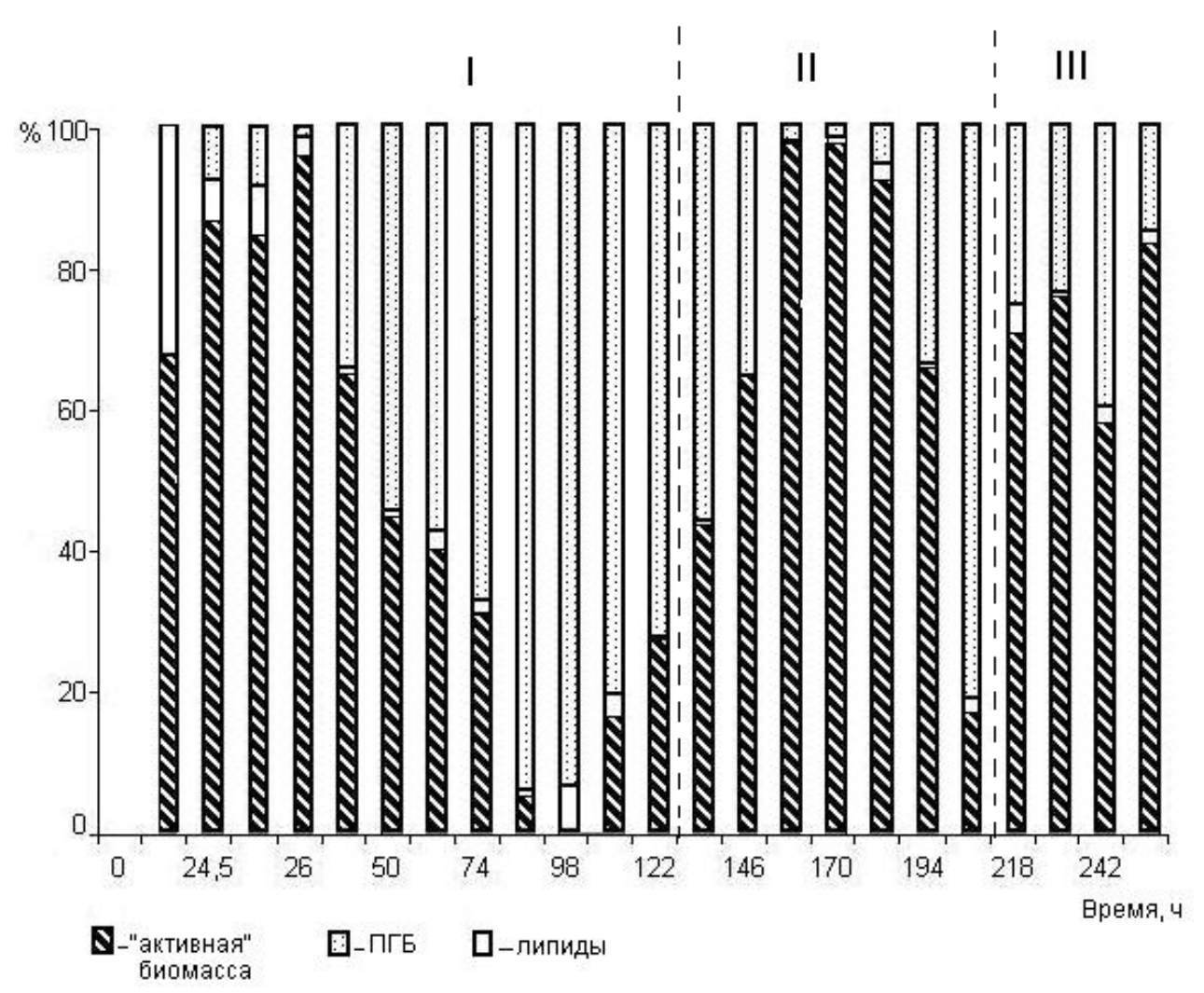

Рис. 3. Распределение радиоуглерода среди липидов, полимера и «активной» биомассы бактерий Cupriavidus eutrophus B-10646 при выращивании на фруктозе при смене режимов «синтез (I) деградация (II) - ресинтез (III) ПГБ»

его содержание в клетках снизилось до 50 \% и оставалось на этом уровне до конца эксперимента. Практически не менялась концентрация и «активной» биомассы. Увеличение ${ }^{14} \mathrm{C}$ в полимере и соответствующее снижение метки в «активной» биомассе отмечалось только на 208-м часу роста культуры, далее содержание метки в этих фракциях снижалось и мало изменялось до конца опыта (рис. 2).

На рис. 3 показано относительное распределение радиоуглерода среди фракций макромолекул - липидов, полимера и «активной» биомассы - при смене режимов «синтездеградация-ресинтез» полигидроксибутирата (рис. 3). В первой точке отбора проб метка в первую очередь включалась в липиды и «активную» биомассу. И только через 0.5 ч после добавления метки наблюдалось небольшое включение ${ }^{14} \mathrm{C}$ в полимер. По мере возрастания пула полимера в клетках концентрирование радиоуглерода в этой фракции увеличивалось (более 85 \%) на фоне снижения радиоактивности в «активной» биомассе (до 11.5 \%). На втором этапе эксперимента, в период деградации полимера, наблюдалось снижение доли радиоактивности во фракции полимера (до $3 \%$ ) и увеличением доли ${ }^{14} \mathrm{C}$ в «активной» биомассе (до 96 \%) (рис 3). При переходе клеток в третий период роста культуры, после исчерпания азота в среде, ресинтез полимера сопровождался увеличением доли меченого углерода во фракции полимера и снижением доли метки в «активной» биомассе. Такое распределение было кратковре- 
Таблица 1. Среднечисловая молекулярная масса $(\mathrm{Mn})$, средневесовая молекулярная масса (Mw) и полидисперсность (Đ) полимера, полученного при выращивании Cupriavidus eutrophus В-10646 при смене режимов «синтез(I)-деградация(II)-ресинтез(III)» полигидроксибутирата при выращивании на фруктозе

\begin{tabular}{|c|c|c|c|}
\hline Час (этап) & Mn, Da & Mw, Da & Đ \\
\hline 98 (І этап) & $308759 \pm 5860$ & $664503 \pm 19945$ & $2.15 \pm 0.005$ \\
\hline 116 (І этап) & $251053 \pm 664$ & $814376 \pm 15926$ & $3.25 \pm 0.070$ \\
\hline 160 (II этап) & $203773 \pm 8163$ & $667977 \pm 21833$ & $3.28 \pm 0.025$ \\
\hline 170 (ІІ этап) & $110475 \pm 74$ & $356012 \pm 2009$ & $3.23 \pm 0.015$ \\
\hline 208 (III этап) & $241102 \pm 692$ & $610957 \pm 1890$ & $2.54 \pm 0.015$ \\
\hline 242 (IIІ этап) & $109156 \pm 692$ & $309765 \pm 1890$ & $2.84 \pm 0.015$ \\
\hline 256 (ІІІ этап) & $156922 \pm 4474$ & $422885 \pm 15566$ & $2.69 \pm 0.025$ \\
\hline
\end{tabular}

менным, и в последние часы роста культуры относительное содержание меченого углерода в полимере снижалось, а в активной биомассе увеличивалось, что может свидетельствовать о деградации полимера в конце эксперимента.

Таким образом, при эндогенной деградации полимера основной поток углеродсодержащих продуктов, образующихся при его деградации, перенаправлялся на синтез азотсодержащих соединений и, наоборот, при исчерпании азота наступала фаза ресинтеза полимера. В период эндогенной деградации полимера его содержание в клетках снижалось (от 88 до 40 \%), при этом молекулярная масса в течение короткого периода времени (6-12 ч) могла резко снизиться в 2-3 раза (от 814 до 300 кДа) (табл. 1). Эти результаты важны для технологии получения ПГБ как в части общих выходов ПГБ, так и его характеристик.

\section{Рост культуры на ацетате}

Рост бактерий C. eutrophus B-10646 на ацетате отличался от роста этих бактерий на фруктозе. Во-первых, бактерии росли менее интенсивно и максимальное накопление биомассы составляло 4.5-4.7 г/л сухого вещества (рис. 4, 5). Во-вторых, в двух сериях экспериментов на ацетате азот в среде до конца не использовался и в фазу синтеза полимера составлял 0.2 г/л (рис. 4,5$)$.

Во втором эксперименте $1,2-{ }^{14} \mathrm{C}$-ацетат был добавлен на 23-й час роста культуры, в период начала синтеза ПГБ, как и на фруктозе, а в 3-м эксперименте - на 115-й час, в фазу деградации ПГБ. Все показатели роста культуры в этих двух опытах практически не различались (рис. 4 и 5).

Максимальных значений биомасса (до 4.5-4.7 г/л) достигала в фазу деградации ПГБ, а затем незначительно падала до 3.9 г/л в фазу ресинтеза полимера и оставалась на этом уровне до конца опытов. Концентрация ПГБ увеличивалась в клетках с 22.4 \% до 71-73\% на первом этапе роста (фаза накопления полимера), снижалась до 49.0 \% в период деградации полимера (2-й этап) и опять возрастала до 70 \% на последнем этапе роста бактерий, но к концу эксперимента снижалась до 46-55 \% (рис. 4, 5).

Во втором эксперименте в течение первого часа культивирования после добавления $1,2-{ }^{14} \mathrm{C}$-ацетата в начале роста (23-й час) количество меченого углерода в культуральной среде снизилось незначительно, и только к 

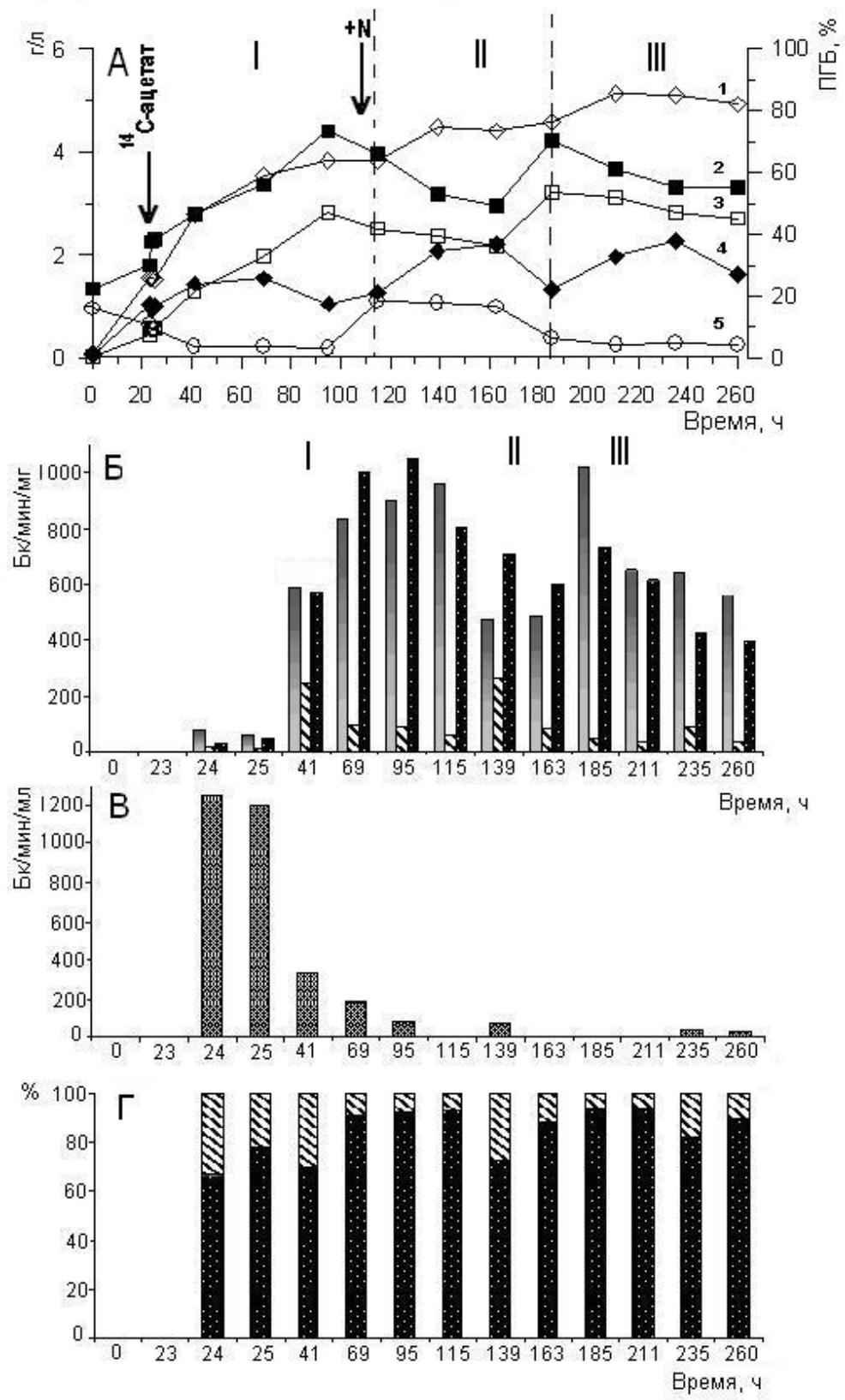

Рис. 4. Показатели культуры Cupriavidus eutrophus В-10646 при выращивании на ацетате (А) (1 - биомасса, г/л; 2 - ПГБ, \%; 3 - «активная» биомасса, г/л; 4 - ПГА, г/л; 5 - азот в среде, г/л); Б - динамика удельной активности радиоуглерода в биомассе (目), «активной» биомассе $(\mathbf{Y})$ и ПГБ $(\mathbf{D}) ; \mathrm{B}-$ в культуральной

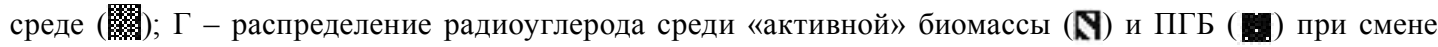
режимов биосинтеза (I), деградации (II) и ресинтеза (III) полимера

41-му часу роста бактерий упало в 6.0 раз, с 1200 до 200 Бк/мин/мл, продолжая снижаться до 100 Бк/мин/мл в конце эксперимента (рис. 4в).
Динамика изменения радиоактивности полимера и «активной» биомассы представлена на рис. 4б. В отличие от эксперимента на фруктозе уже через час после добавления 

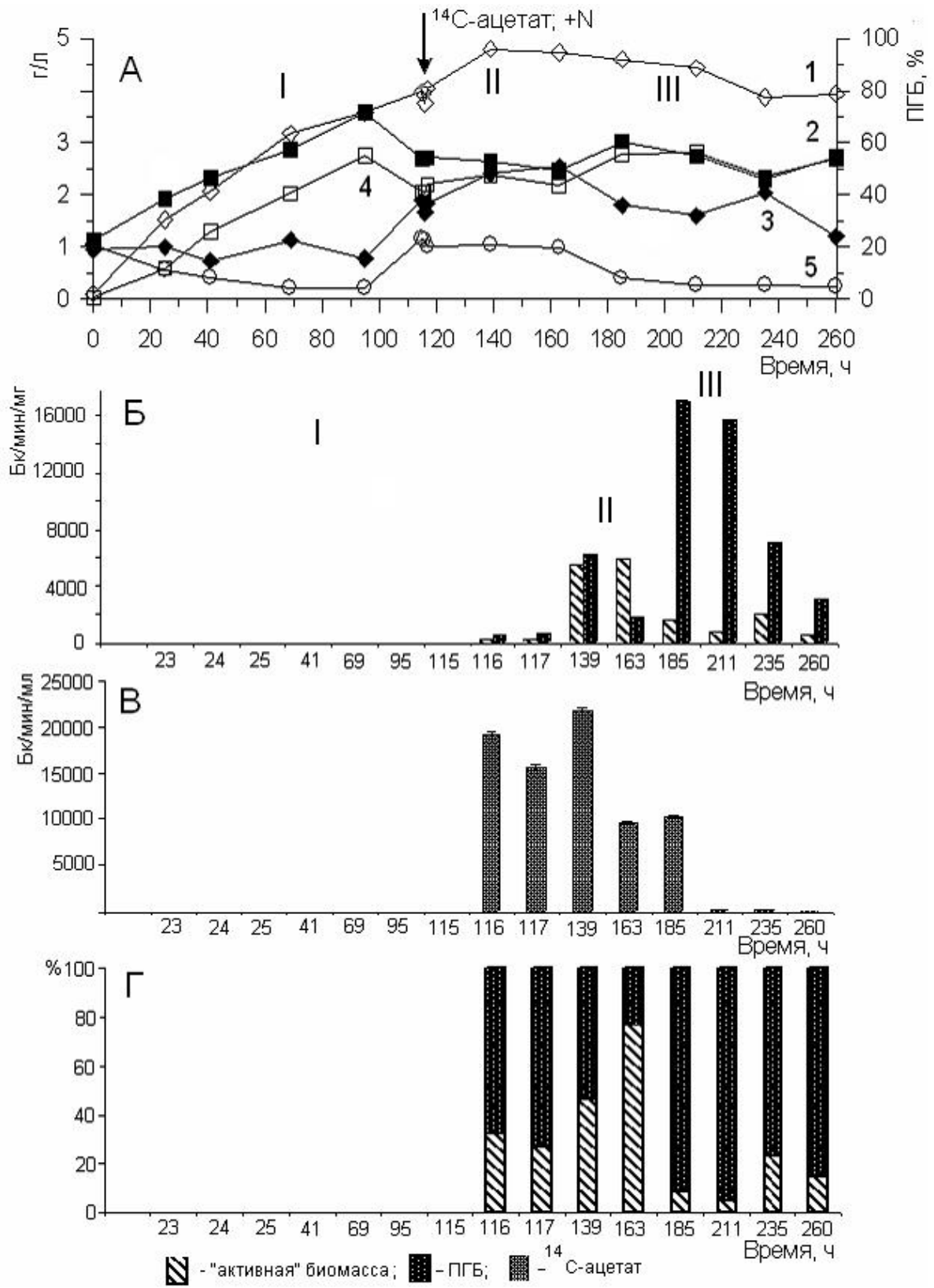

Рис. 5. Показатели культуры Cupriavidus eutrophus B-10646 при выращивании на ацетате, 1,2- ${ }^{14} \mathrm{C}-$-ацетат добавлен в период деградации полимера (А) (1 - биомасса, г/л; 2 - ПГБ, \%; 3 - «активная» биомасса, г/л; 4 ПГА, г/л; 5 - азот в среде, г/л); Б - динамика удельной активности радиоуглерода в «активной» биомассе и ПГБ; В - в культуральной среде; Г - распределение радиоуглерода среди «активной» биомассы и ПГБ при смене режимов биосинтеза (I), деградации (II), ресинтеза (III) ПГБ

меченого ацетата ${ }^{14} \mathrm{C}$ был зафиксирован как в «активной биомассе», так и в полимере (рис. 4б). Причем доля радиоуглерода оставалась всегда выше в полимере, чем в «ак- тивной» биомассе на протяжении всего эксперимента (рис. 4б). Отмечалось снижение радиоактивности в полимере на втором этапе опыта в период деградации с 92 до 72 \% и со- 
ответствующее увеличение в «активной» биомассе с 8 до $28 \%$ (рис. 4г). На третьем этапе эксперимента все показатели включения ${ }^{14} \mathrm{C}$ в полимер и «активную» биомассу вернулись на уровень этапа синетеза полимера, т.е. потоки углерода из системы синтеза основных соединений снова перераспределились на образование полимера.

Вероятность одновременного синтеза и деградации полимера, неоднократно высказываемая рядом исследователей (Doi et al., 1990; Taidi et al., 1995; Shang et al., 2005), была проверена в эксперименте, заключающемся в добавлении $1,2-{ }^{14} \mathrm{C}$-ацетата в культуру бактерий в период эндогенной деградации полимера (рис. 5). Установлено, что уже через час после добавления меченого ацетата ${ }^{14} \mathrm{C}$ был зафиксирован как в «активной биомассе», так и в полимере. К концу первого часа культивирования после добавления $1,2-{ }^{14} \mathrm{C}$-ацетата количество меченого углерода в культуральной среде составило около 20000 Бк/мин/мл и сохранялось на этом уровне в течение 22 ч роста культуры, а затем снизилось практически в 2 раза до 10000 Бк/мин/мл и не менялось в течение последующих 23 ч. На 211-й час культивирования произошло снижение радиоактивности в культуральной среды до 200 Бк/ мин/мл, которая оставалась на этом уровне до конца 3-го этапа эксперимента.

В период внутриклеточной деградации полимера должен реализоваться синтез азотсодержащих соединений, поэтому вполне логично включение ${ }^{14} \mathrm{C}$ в «активную биомассу». Однако на данном этапе, когда происходила деградация полимера, зафиксировано включение радиоуглерода в ПГБ, что свидетельствует об одновременной деградации и синтезе полимера. Показано, что через 1-2 ч после добавления метки основная доля радиоактивности сосредоточена в полимере (до 70 \%) (рис. 5г). В течение последующей деградации полимера (до 162 ч) отмечено снижение относительной радиоактивности ПГБ и увеличение доли в «активной» биомассе (соответственно с 70 до 24 и с 30 до 76 \%). На третьем этапе (начиная с 185 ч) после снижения азота в культуральной среде снова были созданы условия для накопления в клетках полимера. В результате ресинтеза полимера на этом этапе произошло перераспределение ${ }^{14} \mathrm{C}$ : доля радиоуглерода во фракции азотсодержащих веществ снизилась до 5 \%, а в пуле полимера, напротив, увеличивалась до 95 \%. Таким образом, потоки углерода из системы синтеза основных соединений перераспределились на образование полимера.

Известно, что бактериальные клетки, использующие ацетат в качестве основного ростового субстрата, синтезируют все клеточные макромолекулы и поддерживают энергетический статус через цикл трикарбоновых кислот (ЦТК). Это показано в серии работ, в которых описана динамика синтеза ПГА на ацетате различными микробными культурами. При анализе метаболических путей углерода у бактерий A. eutrophus H16 (АТСС 17699) при росте на ацетате было показано, что в условиях лимита по азоту около 50 \% субстрата направляется на синтез полимера, около 40 \% теряется с $\mathrm{CO}_{2}$ и только около $15 \%$ идет на синтез других компонентов клетки (Shi et al., 1997). Подобные результаты получены при росте метилотрофных бактерий Methylobacterium extorquens на $2^{14} \mathrm{C}$-ацетате в азот-дефицитных условиях: $54 \%$ радиоуглерода обнаружено в $\mathrm{CO}_{2}, 35 \%$ - в полимере, $11 \%$ - в биомасcе (Korotkova et al., 1999). Поэтому не удивительно, что в наших экспериментах на ацетате доля включения метки в полимер значительно превышала уровень включения ${ }^{14} \mathrm{C}$ в «активную» биомассу. А в период накопления полимера в C. eutrophus В-10646 основная часть ${ }^{14} \mathrm{C}$ (более $80 \%$ ра- 
диоуглерода) идет на синтез полимера, около 20 \% - на синтез азотсодержащих веществ. В период деградации полимера, как показано, происходил одновременно и его синтез, что согласуется с циклической природой метаболизма полимера в бактериях (Doi et al., 1990; Taidi et al., 1995; Shang et al., 2005).

\section{Заключение}

Показано, что при эндогенной деградации полимера основной поток углеродсодержащих продуктов, образующихся при его деградации, перенаправляется на синтез азотсодержащих соединений и, наобо- рот, при исчерпании азота наступает фаза ресинтеза полимера. В период эндогенной деградации полимера его содержание в клетках может резко снизиться (от 70-80 до 40-50 \% и менее), при этом молекулярная масса в течение короткого периода времени (6-12 ч) резко падает в 2-3 раза (от 800400 до 150 кДа и менее). Синтез полимера у бактерии C. eutrophus B-10646 происходит не только в условиях, оптимальных для его накопления (дефицит азота), но и во время внутриклеточной деградации полимера, что подтверждает предположение циклической природы метаболизма ПГБ.

Работа выполнена за счет средств государственного задания на проведение фундаментальных исследований РАН (проект № гос. регистрации 01201351505).

\section{Список литературы}

1. Волова Т.Г., Калачева Г.С., Константинова В.М., Пузырь А.П. (1992) Влияние условий роста на накопление полиоксибутирата водородными бактериями. Прикладная биохимия и микробиология 28: 221-232 [Volova T.G., Kalacheva G.S., Konstantinova V.M., Puzyr A.P. (1992) Effect of growth conditions on polyhydroxybutyrate accumulation by hydrogen bacteria. Prikl. Biokhim. Mikrobiol. 28: 221-232 (in Russian)].

2. Волова Т.Г., Шишацкая Е.И. Штамм бактерий ВКПМ В-10646 - продуцент полигидроксиалканоатов и способ их получения. Патент РФ №. 2439143. Зарегистрирован 10.01.2012.

3. Brandl H., Gross R.A., Lenz R.W., Fuller C.W. (1988) Pseudomonas oleovorans as a source of poly( $\beta$-hydroxyalkanoates) for potential application as biodegradable polyesters. Appl. Environ. Microbiol. 54: 1977-1982.

4. Doi Y., Segawa A., Kawaguchi Y., Kunioka M. (1990) Cyclic nature of poly(3-hydroxyalkanoate) metabolism in Alcaligenes eutrophus. FEMS Microbiology Letters 67: 165-170.

5. Fukui T., Chou K., Harada K., Orita I., Nakayama Y., Bamba T., Nakamura S., Fukusaki E. (2013) Metabolite profiles of polyhydroxyalkanoate-producing Ralstonia eutropha H16. Metabolomics 10 (2): 190-202.

6. Handrick R., Reinhardt S., Jendrossek D. (2000) Mobizization of poly(3-hydroxybutyrate) in Ralstonia eutropha. J. Bacteriol. 182 (20): 5916-5918.

7. Haywood G.W., Anderson A.J., Dawes E.A. (1989) The importance of PHB-synthase substrate specificity in polyhydroxyalkanoates synthesis by Alcaligenes eutrophus. FEMS Microbiol. Lett. 57: 1-6.

8. Kalacheva G.S., Volova T.G. (2007) Fatty acid composition of Wautersia eutropha lipids under conditions of active polyhydroxyalkanoates synthesis. Microbiology 76 (5): 535-540.

$$
-233-
$$


9. Kobayashi T., Uchino K., Abe T., Saito T. (2005) Novel inutacellula 3-hydroxybutyrate-oligomer hydrolase in Wautersia eutropha H16. J. Bacteriol. 187: 5125-5135.

10. Korotkova N.A., Doronina N.V., Trotsenko Yu.A. (1999) Biosynthesis of the copolymer of 3-hydroxybutyrate and 3-hydroxyvalerate in Methylobacterium extorquens: metabolism of propanol, propionate, pentanol, and valerate. Microbiology 68(3): 296-303.

11. Lawrence A.G., Schoenheit J., He A., Tian J., Liu P., Stubbe J., Sinskey A.J. (2005) Transcriptional analysis of Ralstonia eutropha genes related to poly-(R)-3-hydroxybutyrate homeostasis during batch fermentation. Appl. Microbiol. Biotechnol. 68: 663-672.

12. Lee S.Y. (1996) Bacterial polyhydroxyalkanoates. Biotechnol. Bioengineer. 49: 1-14.

13. Saeguse H., Shiraki M., Kanai C., Saito T. (2001) Cloning intracellular poly[D-(-)3-hydoxybutyrate]- oligomer hydrolase in Ralstonia eutropha H16. J. Bacteriol. 183: 94-100.

14. Schlegel H.G., Kaltwasser H., Gottshalk G. (1961) Ein submersverfahren zur kultur wasserstoffoxydierenden bakterien: wachstumphysiologische untersuchung. Arch. Mikrobiol. 38: 209-222.

15. Shang L., Yim S.C., Park H.G., Chang H.N. (2004) Sequential feeding of glucose and valerate in a fed-batch culture of Ralstonia eutropha for production of poly(hydroxybutyrate-cohydroxyvalerate) with high 3-hydroxyvalerate fraction. Biotechnol. Prog. 20: 140-144.

16. Shi H., Shiraishi M., Shimizu K. (1997) Metabolic flux analysis for biosynthesis of poly( $\beta$ hydroxybutyric acid) in Alcaligenes eutrophus from various carbon sources. Journal of Fermentation and Bioengineering 84: 579-587.

17. Shimizu R., Choi K., Orita I., Suzuki Y., Nakamura S., Fukui T. (2013)Detection of phase-dependent transcriptomic change and Ribosko-mediated $\mathrm{CO}_{2}$ fixation into poly(3-hydroxybutyrate) under heterotrophic condition in Ralstonia eutropha H16 based on RNA-seq and gene deletion analyses. BMC Microbiology 13 (169): 1-14.

18. Sznajder A., Pfeiffer D., Jendrossek D. (2015) Comparative proteome analysis four novel polyhydroxybutyrate (PHB) granule-associated proteins in Ralstonia eutropha H16. Appl. Environ. Micribiol. 85: 1847-1858.

19. Taidi B., Mansfield D.A., Anderson A.J. (1995) Turnover of poly(3-hydroxybutyrate) (PHB) and its influence on the molecular mass of the polymer accumulated by Alcaligenes eutrophus during batch culture. FEMS Microbiology Letters 129: 201-206.

20. Vaneechoutte M., Kampfer P., De Baere T., Falsen E., Verschraegen G. (2004) Wautersia gen. nov., a novel genus accommodating the phylogenetic lineage including Ralstonia eutropha and related species, and proposal of Ralstonia [Pseudomonas] syzygii (Roberts et al. 1990) comb. nov. Int. J. Syst. Evol. Microbiol. 54: 317-327.

21. Volova T.G., Kalacheva G.S, Gorbunova O.V., Zhila N.O. (2004) Dynamics of activity of the key enzymes of polyhydroxyalkanoate metabolism in Ralstonia eutropha B5786. Appl. Biochem. Microbiol. 40 (2): 170-177.

22. Volova T.G., Kiselev E.G., Shishatskaya E.I., Zhila N.O., Boyandin A.N., Syrvacheva D.A., Vinogradova O.N., Kalacheva G.S., Vasiliev A.D., Peterson I.V. (2013) Cell growth and accumulation of polyhydroxyalkanoates from $\mathrm{CO}_{2}$ and $\mathrm{H}_{2}$ of a hydrogen-oxidizing bacterium, Cupriavidus eutrophus B-10646. Biores.Technol. 146: 215-222. 
23. Volova T., Kiselev E., Vinogradova O., Nikolaeva E., Chistyakov A., Sukovatiy A., Shishatskaya E.I. (2014) A glucose-utilizing strain, Cupriavidus euthrophus B-10646: growth kinetics, characterization and synthesis of multicomponent PHAs. PLOS ONE 9: 1-15.

24. Uchino K., Saito T. (2006) Thiolysis of poly(3-hydroxybutyrate) with polyhydroxyalkanoate synthase from Ralstonia eutropha. J. Biochem. 139: 615-621.

25. Uchino K., Saito T., Gebauer B., Jendrossek D. (2007) Isolated poly(3-hydroxybutyrate) (PHB) granules are complex bacterial organelles catalyzing formation of PHB from acetyl coenzyme A (CoA) and degradation of PHB to acetyl-CoA. J. Bacteriol. 189 (22): 8250-8256. 